\title{
Interpretasi Tingkat Kekerasan Batuan Bawah Permukaan di Daerah Rawan Gempa Bumi Kota Bengkulu
}

\author{
Arif Ismul Hadi ${ }^{*}$ Refrizon, Halauddin, Liza Lidiawati, dan Paisal Edo \\ Jurusan Fisika, Fakultas MIPA, Universitas Bengkulu, Bengkulu \\ *Email: ismulhadi@unib.ac.id
}

\begin{abstract}
Bengkulu City is located in the subduction zone of the Indo-Australian and Eurasian plates, so it is prone to earthquake. To anticipate the impact of earthquake, disaster mitigation can be carried out, one of which is a study of the level of rock hardness in the area. This study aims to determine the level of rock hardness based on seismic wave velocity in several rock formations and to determine which rock formations have the potential to cause vulnerability to earthquakes. Field data acquisition uses the seismic refraction method with time-term inversion technique. The data obtained in the field are processed to obtain a 2-D cross-section of the subsurface seismic wave velocity values. The study results show that the level of rock hardness depends on the type of rock formation. The Andesite Rock Formation Unit (Tpan) has the highest level of hardness, while the transitional area between the Alluvium Rock Formation Unit (Qa) and the Swamp Sedimentary Rock Formation Unit (Qs) has the lowest level of hardness.
\end{abstract}

Keywords : Bengkulu City, earthquake, rock hardness, time-term inversion, vulnerability.

\section{ABSTRAK}

Kota Bengkulu berada di daerah zona subduksi lempeng Indo-Australia dan Eurasia, sehingga rawan terhadap gempa bumi. Untuk mengantisipasi dampak gempa bumi dapat dilakukan melalui mitigasi bencana yang salah satunya berupa studi tentang tingkat kekerasan batuan di daerah tersebut. Penelitian ini bertujuan untuk menentukan tingkat kekerasan batuan berdasarkan kecepatan gelombang seismik pada beberapa formasi batuan dan mengetahui formasi batuan yang berpotensi menyebabkan kerentanan terhadap bencana gempa bumi. Akuisisi data lapangan menggunakan metode seismik refraksi dengan teknik time-term inversion. Data yang diperoleh di lapangan diolah untuk mendapatkan penampang model 2-D dari nilai kecepatan gelombang seismik bawah permukaan. Hasil studi menunjukkan bahwa tingkat kekerasan batuan bergantung pada jenis formasi batuannya. Satuan Formasi Batuan Andesit (Tpan) mempunyai tingkat kekerasan paling tinggi, sedangkan daerah peralihan antara Satuan Formasi Batuan Aluvium (Qa) dan Satuan Formasi Batuan Endapan Rawa (Qs) mempunyai tingkat kekerasan paling rendah.

Kata kunci: Kota Bengkulu, gempa bumi, kekerasan batuan, time-term inversion, kerentanan. 


\section{PENDAHULUAN}

Kota Bengkulu berada di daerah zona subduksi lempeng Indo-Australia dan Eurasia. Kondisi ini menyebabkan Kota Bengkulu rawan terhadap gempa bumi ${ }^{[1]}$. Sekitar 95\% sumber gempa bumi berada di zona tersebut akibat pergerakan-pergerakan lempeng tektonik tersebut ${ }^{[2]}$. Gempa bumi tersebut dapat memberikan dampak kerugian sosial dan ekonomi pada masyarakat, seperti korban jiwa, harta benda dan kerusakan sarana umum berupa bangunan, transportasi maupun kejadian abrasi, longsor, maupun likuifaksi. Kerusakan sarana umum akibat gempa bumi banyak dipengaruhi oleh tingkat kekerasan batuan yang menopang bangunan di atasnya.

Gempa bumi merupakan suatu fenomena alam yang belum dapat diperkirakan secara tepat [3]. Untuk mengantisipasi dampak bahaya gempa bumi dapat dilakukan melalui mitigasi bencana. Salah satu upaya mitigasi bencana gempa bumi adalah melakukan studi tentang tingkat kekerasan batuan di daerah rawan gempa bumi Kota Bengkulu.

Berdasarkan kondisi geologisnya, sebagian besar wilayah di Kota Bengkulu terdiri dari material lunak berupa pasir, kerikil, lumpur, dan tanah liat yang rentan terhadap ancaman gempa bumi ${ }^{[4,5]}$. Adapun formasi batuan di Kota Bengkulu terdiri dari formasi batuan berupa Undak Aluvium (Qat), Formasi Bintunan (QTb), Endapan Rawa (Qs), Batu gamping Terumbu (Q1), Andesit (Tpan), dan Aluvium (Qa) ${ }^{[6,7]}$. Untuk mengetahui tingkat kekerasan dari formasi-formasi batuan tersebut dapat dilakukan menggunakan beberapa metode geofisika yang salah satunya adalah metode seismik refraksi dengan teknik timeterm inversion. Parameter yang digunakan dalam penentuan tingkat kekerasan batuan tersebut berupa kecepatan gelombang seismik. Untuk itu penelitian ini sangat penting dilakukan karena berdasarkan interpretasi tingkat kekerasan batuan maka dapat diketahui formasi batuan yang dapat berpotensi menyebabkan kerentanan terhadap bencana gempa bumi.

Penelitian tentang tingkat kekerasan batuan bawah permukaan menggunakan metode seismik refraksi dengan teknik time-term inversion di daerah studi belum banyak dilakukan. Namun demikian penelitian yang berkaitan dengan mitigasi bencana gempa di daerah ini telah banyak dilakukan dengan berbagai parameter yang berbeda. Hadi et al. ${ }^{[1]}$ melakukan pemetaan peak ground acceleration (PGA) dan kerentanan seismik akibat gempa bumi di Kota Bengkulu. Penelitian ini menggunakan data mikrotremor. Hasil penelitian menunjukkan bahwa daerah yang paling rawan terhadap dampak gempa bumi berada di sekitar Kecamatan Kampung Melayu dengan nilai PGA 0,3 g dan berada pada tingkat risiko besar tiga dan risiko sangat besar. Selanjutnya Mase et al. ${ }^{[8]}$ menggunakan data mikrotremor dan teknik inversi untuk mendapatkan nilai kecepatan gelombang sekunder $\left(V_{s}\right)$. Hasil penelitian menunjukkan bahwa berdasarkan kriteria dari National Earthquake Hazard Reduction Program (NEHRP), Kota Bengkulu didominasi oleh kelas situs C (tanah sangat padat/batuan lunak) dan situs D (tanah sedang). Hasil penelitian ini merekomendasikan kepada Pemerintah Kota Bengkulu untuk mempertimbangkan kembali mitigasi bahaya gempa untuk rencana tata ruang.

Farid dan Mase ${ }^{[9]}$ melakukan pemetaan bahaya gempa berdasarkan indikator regangan geser tanah di Kota Bengkulu. Berdasarkan studi ini Kota Bengkulu secara umum rentan terkena dampak gempa bumi khususnya di wilayah pesisir yang dapat berdampak terhadap terjadinya likuifaksi. Potensi terjadinya likuifaksi di wilayah ini cukup besar yakni sekitar $50 \%{ }^{[4]}$. Hasil studi ini juga bersesuaian dengan studi Sugianto et al. ${ }^{[10]}$ yang menyatakan bahwa daerah pesisir Kota Bengkulu memiliki nilai regangan geser tanah paling tinggi dengan formasi geologi berupa Undak Aluvium. 
Penelitian analisis kecepatan gelombang seismik bawah permukaan akibat gempa bumi tanggal 4 Juni 2000 di Kota Bengkulu telah dilakukan oleh Lubis dan Hadi [11] dengan interpretasi sistem Hagiwara. Hasil penelitian menunjukkan bahwa daerah yang paling ringan kerusakannya akibat gempa bumi memiliki kecepatan gelombang seismik paling tinggi. Kemudian Nurcandra et al. ${ }^{[12]}$ memanfaatkan metode seismik refraksi untuk menentukan tingkat kekerasan batuan di daerah Jatikuwung, Karangnyar, Jawa Tengah. Pemrosesan data pada penelitian ini menggunakan teknik intercept time. Hasil penelitian menunjukkan bahwa batuan paling keras yang merupakan batuan dasar terdapat pada kedalaman antara $12 \mathrm{~m}-20 \mathrm{~m}$. Akpan et al. ${ }^{[13]}$ meneliti penyebab longsor di Odukpani, Nigeria dari data seismik refraksi. Berdasarkan penelitian tersebut dapat diketahui bahwa bidang gelincir di daerah tersebut berupa serpih (shale) dengan rata-rata nilai kecepatan gelombang $P\left(V_{p}\right)$ adalah $1787 \mathrm{~m} / \mathrm{s}-1820 \mathrm{~m} / \mathrm{s}$, sedangkan lapisan lapuk berada di atasnya dengan $V_{p}$ adalah $655 \mathrm{~m} / \mathrm{s}-1381 \mathrm{~m} / \mathrm{s}$. Mahandani ${ }^{[14]}$ menggunakan metode seismik refraksi untuk identifikasi kerawanan tanah longsor di Desa Purwosari Kabupaten Kulonprogo, Jawa Timur. Hasil penelitian menunjukkan bahwa nilai kecepatan gelombang seismik yang rendah berkaitan dengan lapisan lapuk yang tidak kompak. Hasil-hasil studi di atas secara umum berkaitan dengan penentuan tingkat kekerasan batuan dengan berbagai macam parameter yang digunakan khususnya untuk keperluan mitigasi bencana. Untuk itu pada studi ini khusus dikaji interpetasi kekerasan batuan bawah permukaan menggunakan metode seismik refraksi dengan teknik time-term inversion di daerah rawan gempa bumi Kota Bengkulu.

Time-term inversion adalah salah satu teknik akuisisi data dalam metode seismik refraksi yang bertujuan untuk menentukan kondisi bawah permukaan dangkal menggunakan penjalaran gelombang $P$. Prinsip utama metode ini adalah pemanfaatan waktu tiba pertama gelombang baik langsung maupun gelombang refraksi ${ }^{[15]}$. Gelombang yang dibangkitkan pada permukaan bumi akan merambat ke dalam bawah permukaan melalui suatu medium atau batuan. Pada suatu titik bidang batas antara dua lapisan batuan selanjutnya gelombang tersebut terpantul kembali ke permukaan bumi dan sebagian diteruskan ke bawah dan sebagian lagi dibiaskan akibat adanya perubahan densitas batuan [16,17]. Kecepatan gelombangnya diperoleh dari analisis traveltime gelombang yang pertama kali terekam oleh geofon sehingga didapatkan kurva traveltime vs jarak. Kurva traveltime vs jarak ini adalah representasi dari kondisi bawah permukaan ${ }^{[18]}$.

Pada teknik time-term ini, pendekatan linier kuadrat-terkecil digunakan untuk menentukan penyelesaian susunan per lapisan terbaiknya dimana hanya dibutuhkan penandaan lapisan untuk setiap first break dalam analisis data traveltime dan waktu tunda akan dihitung secara otomatis ${ }^{[19]}$. Untuk itu dibutuhkan minimal dua shot point yang diletakkan secara bersama dalam analisis data traveltime tersebut. Model inversi yang didapatkan adalah model penyederhanaan lapisan bawah permukaan. Menurut model inversi ini, refraktor digambarkan di bawah geofon pertama dari shot point pertama hingga geofon pertama dari shot point terakhir yang merupakan kombinasi antara forward dari shot point pertama dengan reverse dari shot point terakhir. Supaya didapatkan gambaran refraktor tepat di bawah geofon pertama hingga geofon terakhir, maka posisi shot point pertama dan shot point terakhir harus ditempatkan di luar susunan geofon ${ }^{[20]}$. Pendekatan matematis secara sederhana dapat diasumsikan bahwa refraktor adalah sejajar dengan permukaan tanah (Gambar 1), sehingga waktu tempuh total dari sumber ke penerima adalah ${ }^{[19]}$, 


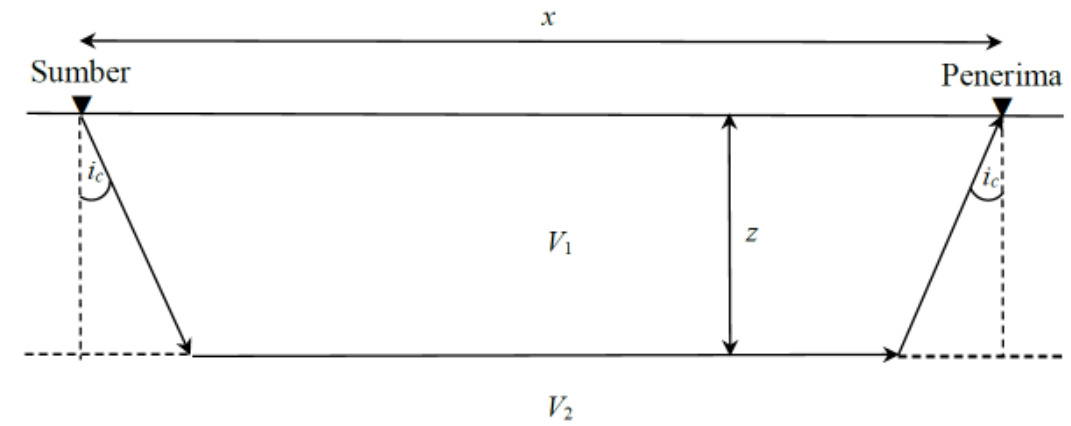

Gambar 1. Penjalaran gelombang pada refraktor yang sejajar dengan permukaan tanah ${ }^{[19]}$

$$
t=2 S_{1} \cos \left(i_{c}\right) z+x S_{2}
$$

dengan $S$ merupakan Slowness atau kebalikan dari kecepatan $(V)$ dan dari Hukum Snellius,

$$
\sin \left(i_{c}\right)=\frac{S_{2}}{S_{1}}
$$

Apabila didefinisikan,

$$
c=2 S_{1} \cos \left(i_{c}\right)
$$

maka,

$$
t=2 c z+x S_{2},
$$

$z$ dan $S_{2}$ tidak diketahui. Untuk kasus umum pada permukaan melengkung non-paralel (Gambar 2), penyelesaian parameter lebih dari dua yakni $z_{1}, z_{2}$, dan $S_{2}$, maka waktu penjalaran gelombang totalnya adalah,

$$
t=c z_{1}+c z_{2}+x S_{2},
$$

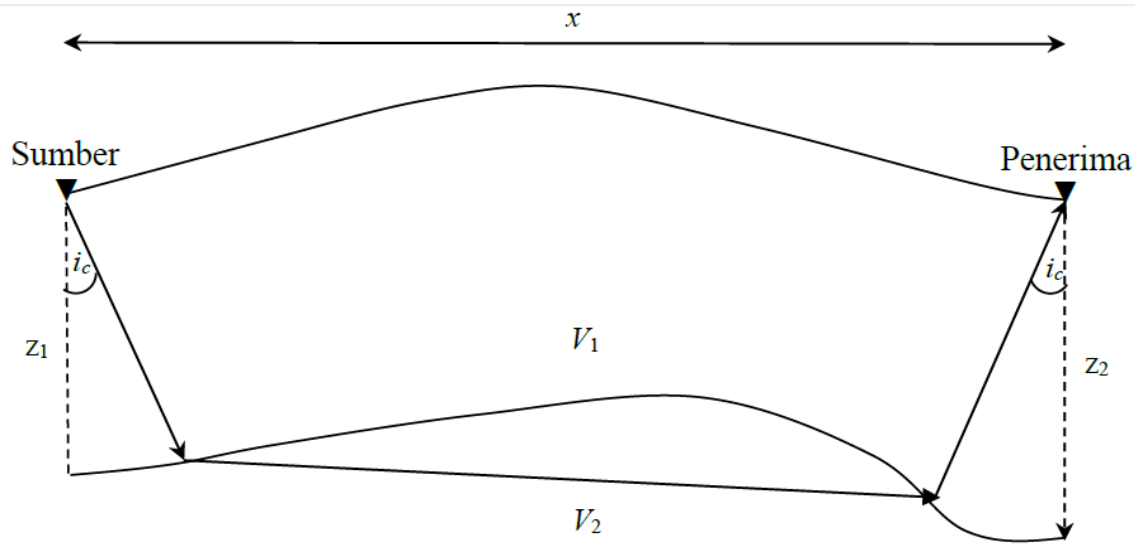

Gambar 2. Penjalaran gelombang pada permukaan melengkung non-paralel ${ }^{[19]}$

sehingga didapatkan,

$$
t_{j}=\sum_{k=1}^{n} c_{j k} z_{k}+x_{j} S_{2}
$$


dan bentuk matriksnya adalah sebagai berikut,

$$
\left[\begin{array}{cccccc}
c_{11} & c_{12} & c_{13} & \cdot & c_{1 n} & x_{1} \\
c_{21} & c_{22} & c_{23} & \cdot & c_{2 n} & x_{2} \\
c_{31} & c_{32} & c_{33} & \cdot & c_{3 n} & x_{3} \\
c_{41} & c_{42} & c_{42} & \cdot & c_{4 n} & x_{4} \\
\cdot & \cdot & \cdot & \cdot & \cdot & \cdot \\
c_{m 1} & c_{m 2} & c_{m 3} & \cdot & c_{m n} & x_{m}
\end{array}\right]\left[\begin{array}{l}
z_{1} \\
z_{2} \\
z_{3} \\
\cdot \\
z_{n} \\
S_{2}
\end{array}\right]=\left[\begin{array}{l}
t_{1} \\
t_{2} \\
t_{3} \\
t_{4} \\
\cdot \\
t_{m}
\end{array}\right],
$$

dengan $m$ adalah jumlah waktu penjalaran dan $n$ adalah jumlah penerima (kedalaman yang dihitung), sehingga diperoleh penyelesaian matriks untuk $z_{1} \ldots . z_{n}$, dan $S_{2}$.

\section{METODE}

Penelitian ini menggunakan seperangkat alat seismograph digital 16S24-P dengan 24 geophone channel. Jarak antar geophone dan offset disesuaikan dengan kondisi lapangan setempat. Sampling rate yang digunakan adalah $125 \mu$ s dan recording time-nya adalah 512 ms. Output dari metode time-term inversion berupa nilai kecepatan gelombang $P$ (profil $V_{p}$ ) pada tiap-tiap lapisan di sepanjang lintasan pengukuran.

Untuk akuisisi data lapangan menggunakan sumber buatan dari palu seberat $\pm 5 \mathrm{~kg}$. Sumber buatan tersebut diletakkan di luar bentangan geofon dan di dalam geofon. Untuk sumber di luar bentangan geofon, sumber diletakkan dekat geofon pertama dan dekat geofon terakhir. Adapun di dalam bentangan, sumber diletakkan pada 1/4 jarak bentangan, $1 / 2$ jarak bentangan, dan $3 / 4$ jarak bentangan, sehingga jumlah total sumber adalah lima buah. Karena dalam teknik time-term inversion dibutuhkan minimal dua sumber di luar bentangan dan sumber-sumber yang lain dibutuhkan untuk meminimalisir error dalam pengolahan data. Ilustrasi akuisisi data lapangan dengan teknik time-term inversion dapat dilihat pada Gambar 3.

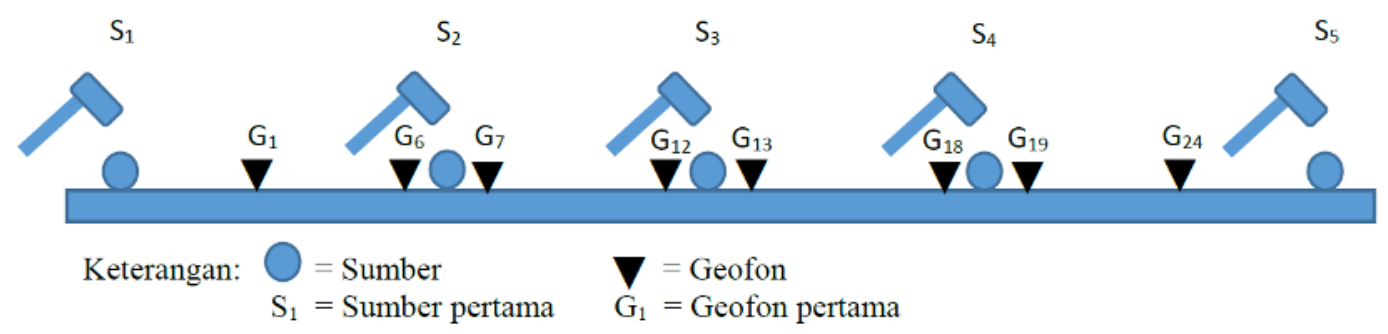

Gambar 3. Ilustrasi akuisisi data lapangan menggunakan teknik time-term inversion

Data yang diperoleh di lapangan kemudian diolah dengan Software SeisImager/2-D yang terdiri dari Program Pickwin dan Plotrefa. SeisImager/2D merupakan paket program inversi untuk menentukan ketebalan lapisan dari permukaan tanah hingga kedalaman tertentu. Data lapangan (shotgather) yang sudah dikonversi ke dalam format SU tersebut diinputkan ke dalam Program Pickwin. Langkah berikutnya adalah memasukkan parameter geometri data shotgather sesuai kondisi pada saat akuisisi data lapangan. Selanjutnya ditentukan picking first break data shotgather pada masing-masing shot. Data shotgather yang sudah di-picking tersebut selanjutnya dilakukan penentuan layer arrival dan batas lapisan dalam Program Plotrefa dengan terlebih dahulu memasukkan data elevasi. Langkah berikutnya adalah melakukan proses inversi. Proses inversi dilakukan secara otomatis hingga diperoleh error minimal. Hasil proses inversi berupa model $V_{p}$ 
awal. Untuk selanjutnya dilakukan raytracing hingga didapatkan hasil pengamatan vs teortis. Setelah itu dapat diperoleh model $V_{p}$ akhir berupa penampang model 2-D yang selanjutnya siap untuk dianalisis ${ }^{[19]}$.

Interpetasi data dengan teknik time-term inversion didasarkan pada $V_{p}$ yang melewati batuan bawah permukaan sepanjang lintasan pengukuran berupa penampang model 2-D. Dengan mencocokan nilai $V_{p}$ yang melewati medium batuan pada masing-masing lapisan, maka dapat diketahui tingkat kekerasan batuannya ${ }^{[21]}$. Tingkat kekerasan batuan dapat juga diasosiasikan dengan densitas bulk batuannya ${ }^{[22]}$. Berdasarkan percobaan secara empiris diperoleh hubungan densitas bulk $\left(\rho_{b}\right)$ dengan kecepatan gelombang $P\left(V_{p}\right)$ yang mewakili rata-rata pada banyak jenis batuan ${ }^{[23,24]}$ yaitu

$$
\rho_{b}=1,741 V_{p}^{0,25}
$$

dengan $\rho_{b}$ dalam satuan $\mathrm{g} / \mathrm{cm}^{3}$ dan $V_{p}$ dalam satuan $\mathrm{km} / \mathrm{s}$.

\section{HASIL DAN PEMBAHASAN}

Penelitian ini dilaksanakan dengan mengambil data seismik refraksi pada formasi batuan yang berbeda sebagaimana ditunjukkan pada Gambar 4. Jumlah titik pengukuran adalah enam buah lintasan dengan arah lintasan disesuaikan dengan kondisi lapangan. Jarak antar geofon pada masing-masing lintasan adalah dua meter. Lima buah sumber seismik diletakkan di luar dan di dalam bentangan geofon. Sumber seismik pertama (S1) dan sumber seismik kelima (S5) terletak di luar geofon, sedangkan sumber seismik kedua (S2), ketiga (S3), dan keempat (S4) terletak di dalam bentangan geofon. Data shotgather dengan sumber-sumber seismik ditampilkan pada Gambar 5. Sumber seismik S1 terletak $6 \mathrm{~m}$ dari geofon pertama (Gambar 5a), sumber seismik S2 terletak di antara geofon 6 dan 7 (Gambar 5b), sumber seismik S3 terletak di antara geofon 12 dan 13 atau di tengah-tengah bentangan (Gambar 5c), sumber seismik S4 terletak di antara geofon 18 dan 19 (Gambar 5d), sedangkan sumber seismik S5 terletak $6 \mathrm{~m}$ dari geofon terakhir (Gambar 5e).

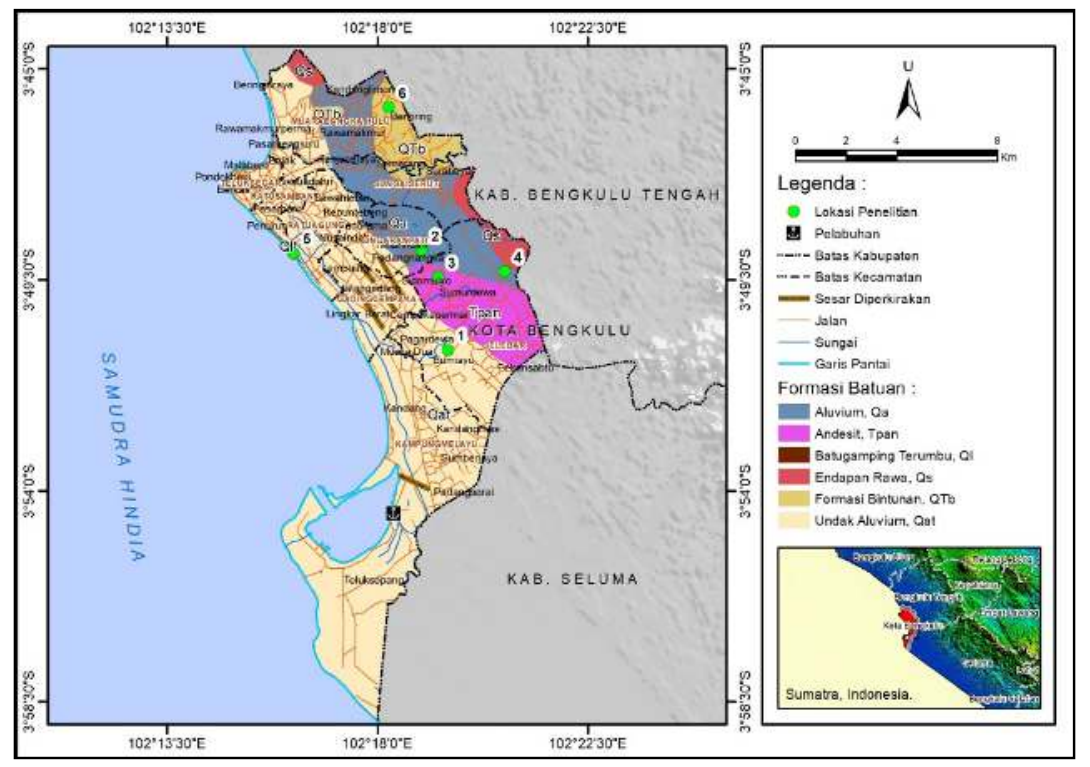

Gambar 4. Lokasi penelitian dengan titik-titik pengukuran data lapangan (Penyederhaan dari ${ }^{[6]}$ ) 

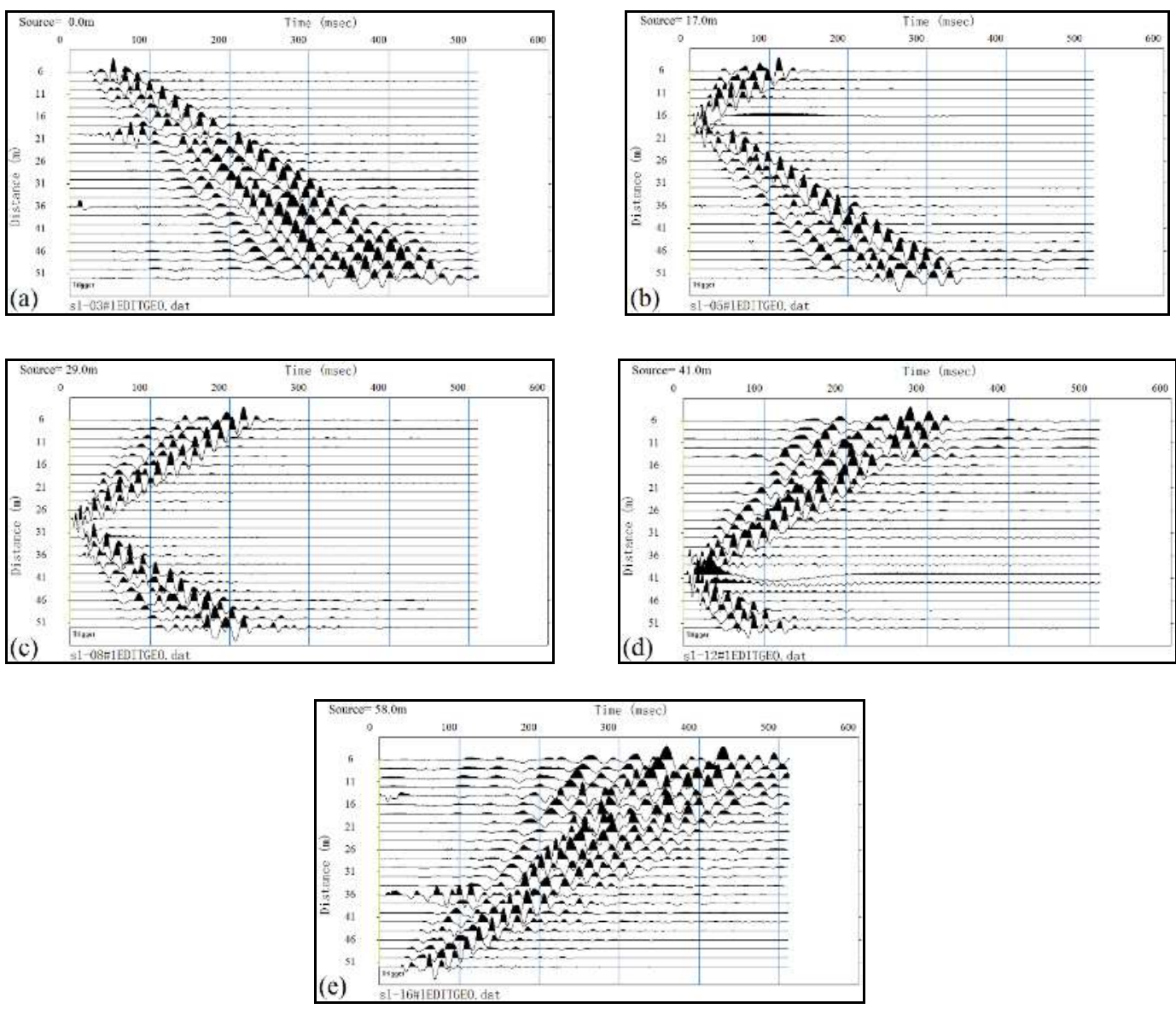

Gambar 5. Data shotgather dengan sumber seismik: (a) sumber pertama (S1), (b) sumber kedua (S2), (c) sumber ketiga (S3), (d) sumber keempat (S4), dan (e) sumber kelima (S5)

Sebelum diperoleh hasil akhir penampang model 2-D $V_{p}$ perlu dihitung root mean square error (RMSE). RMSE didapatkan dari perbandingan antara data lapangan (observed) dengan data model (calculated). Untuk memperoleh nilai RMSE minimal dilakukan dengan menandai masing-masing lapisan pada tiap titik pengukuran. Semakin kecil nilai RMSE, maka model yang dihasilkan semakin mendekati data lapangan. Hal ini menunjukkan bahwa kualitas data yang dihasilkan semakin baik. Pada penelitian ini diperoleh RMSE antara 4,12 ms - 13,58 ms. Salah satu contoh perbandingan nilai RMSE antara data lapangan (observed) dan data model (calculated) ditampilkan pada Gambar 6. Adapun nilai-nilai RMSE dan arah lintasan pengukurannya pada masing-masing lokasi penelitian ditunjukkan pada Tabel 1. Nilai RMSE yang paling rendah diperoleh pada lokasi 3 yaitu 4,12 ms dan nilai RMSE tertinggi berada pada lokasi 4 yaitu 13,58 ms. 


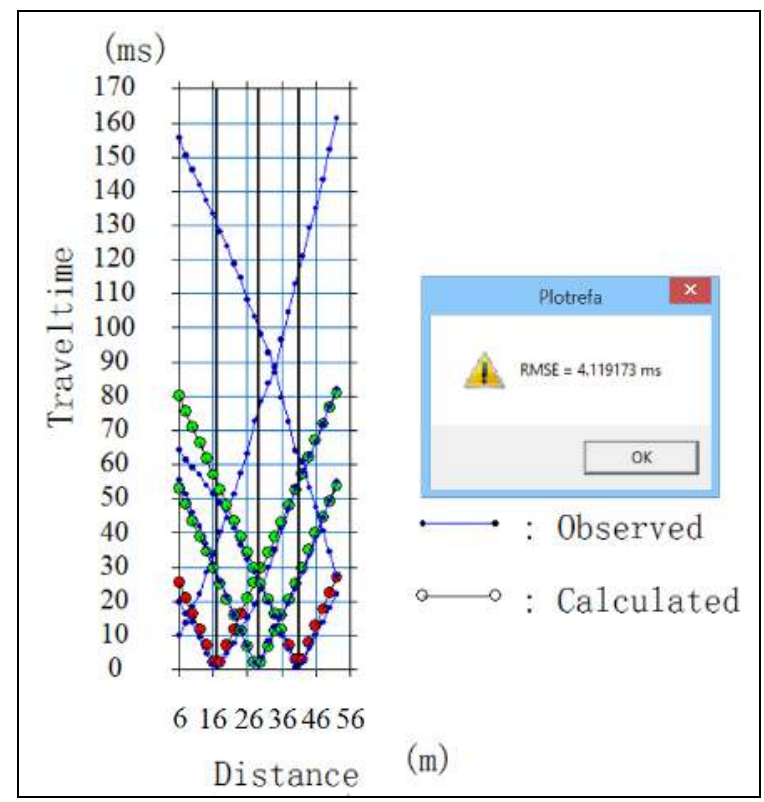

Gambar 6. Contoh perbandingan nilai RMSE antara data lapangan (observed) dan data model (calculated) pada lokasi 3 dengan $\mathrm{RMSE}=4,12 \mathrm{~ms}$

Tabel 1. Nilai-nilai RMSE pada masing-masing lokasi penelitian di Kota Bengkulu

\begin{tabular}{ccccc}
\hline Lokasi & Kelurahan & Kecamatan & Arah lintasan & RMSE (ms) \\
\hline 1 & Bumiayu & Kampung Melayu & N 5 $5^{\circ}$ & 8,50 \\
2 & Timur Indah Ujung & Singaranpati & N 140 E & 6,99 \\
3 & Sumur Dewa & Selebar & N $105^{\circ} \mathrm{E}$ & 4,12 \\
4 & Sukarami & Selebar & N 25 E & 13,58 \\
5 & Nusa Indah & Ratu Agung & N 150 E & 8,89 \\
6 & Bentiring & Muara Bangkahulu & N 80 E & 5,97 \\
\hline
\end{tabular}

Setelah diperoleh nilai RMSE pada masing-masing lokasi penelitian, selanjutnya dibuat penampang model 2-D $V_{p}$. Penampang model 2-D $V_{p}$ pada setiap lokasi penelitian ditunjukkan pada Gambar 7 - Gambar 12.

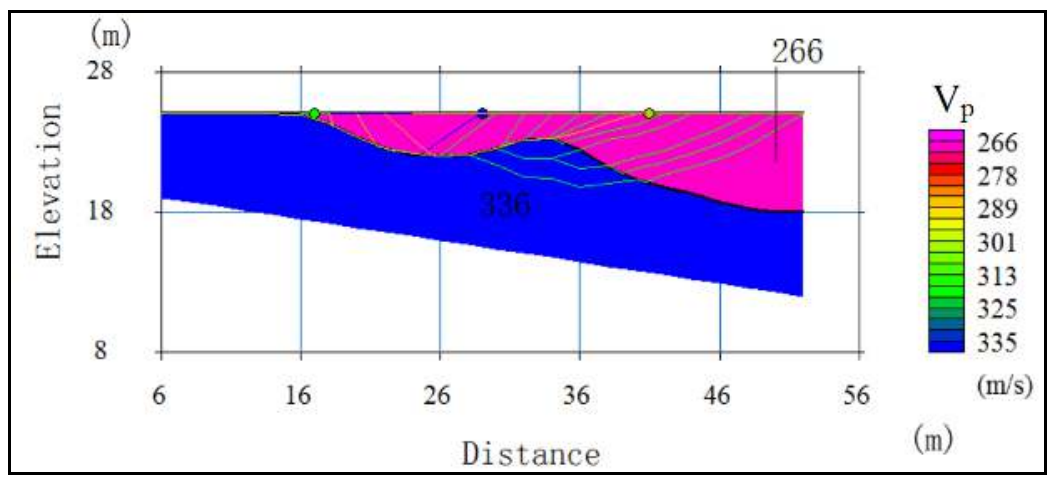

Gambar 7. Penampang model 2-D kecepatan gelombang $P\left(V_{p}\right)$ pada lokasi 1 


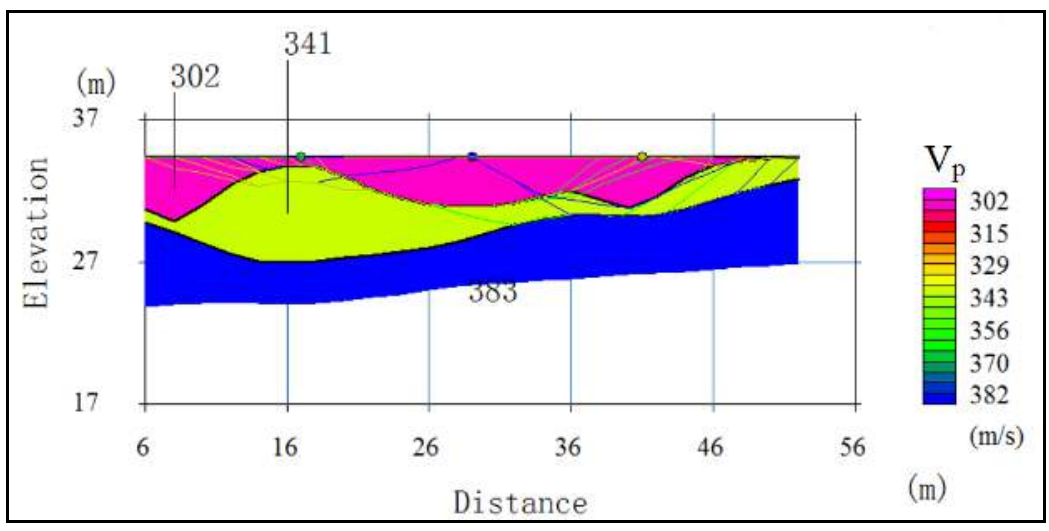

Gambar 8. Penampang model 2-D kecepatan gelombang $P\left(V_{p}\right)$ pada lokasi 2

Berdasarkan penampang model 2-D (Gambar 7) menunjukkan bahwa $V_{p}$ pada lapisan 1 adalah $266 \mathrm{~m} / \mathrm{s}$ dan pada lapisan 2 adalah $336 \mathrm{~m} / \mathrm{s}$. Lokasi ini terletak di Kelurahan Bumiayu Kecamatan Kampung Melayu pada Satuan Formasi Undak Aluvium (Qat). Secara stratigrafi Qat di Kota Bengkulu berumur Holosen dengan urutan Sedimen Kuarter. Untuk lokasi 2 terletak di Kelurahan Timur Indah Ujung Kecamatan Singaranpati dengan formasi batuan berupa Aluvium (Qa) (Gambar 8). Kecepatan gelombang $P\left(V_{p}\right)$ pada lokasi 2 ini adalah $302 \mathrm{~m} / \mathrm{s}$ (lapisan pertama), $341 \mathrm{~m} / \mathrm{s}$ (lapisan kedua), dan $383 \mathrm{~m} / \mathrm{s}$ (lapisan 3). Satuan Formasi Batuan Aluvium (Qa) juga mempunyai umur Holosen dan termasuk dalam Sedimen Kuarter. Lokasi 3 terletak di Kelurahan Sumur Dewa Kecamatan Selebar (Gambar 9) dengan kecepatan gelombang $P\left(V_{p}\right)$ pada lapisan pertama adalah 433 $\mathrm{m} / \mathrm{s}$ dan pada lapisan kedua adalah $444 \mathrm{~m} / \mathrm{s}$. Lokasi ini termasuk dalam Satuan Batuan Formasi Andesit (Tpan). Tpan merupakan formasi batuan Tersier dan merupakan formasi tertua di daerah studi yang berumur Miosen Akhir atau lebih muda ${ }^{[7]}$.

Lokasi 4 berada di Kelurahan Sukarami Kecamatan Selebar (Gambar 10) dengan formasi batuan berupa Aluvium (Qa) yang termasuk dalam urutan Kuarter yang berumur Holosen [7]. Namun lokasi ini berbatasan atau berdekatan dengan formasi batuan berupa Endapan Rawa (Qs). Kecepatan gelombang $P\left(V_{p}\right)$ di lokasi ini adalah $225 \mathrm{~m} / \mathrm{s}$ pada lapisan pertama dan $300 \mathrm{~m} / \mathrm{s}$ pada lapisan kedua. Nilai $V_{p}$ ini merupakan nilai yang terkecil pada semua lokasi studi. Kecilnya nilai $V_{p}$ diduga berkaitan dengan lokasinya yang berdekatan dengan Formasi Endapan Rawa (Qs) yang merupakan batuan kurang solid, sehingga berpengaruh terhadap besarnya nilai $V_{p}$ yang diperoleh di lokasi ini.

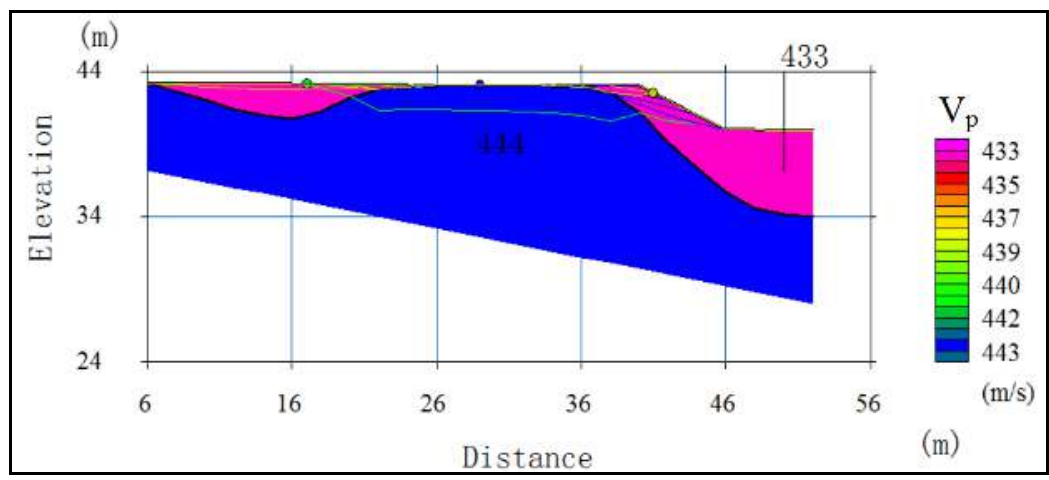

Gambar 9. Penampang model 2-D kecepatan gelombang $P\left(V_{p}\right)$ pada lokasi 3 


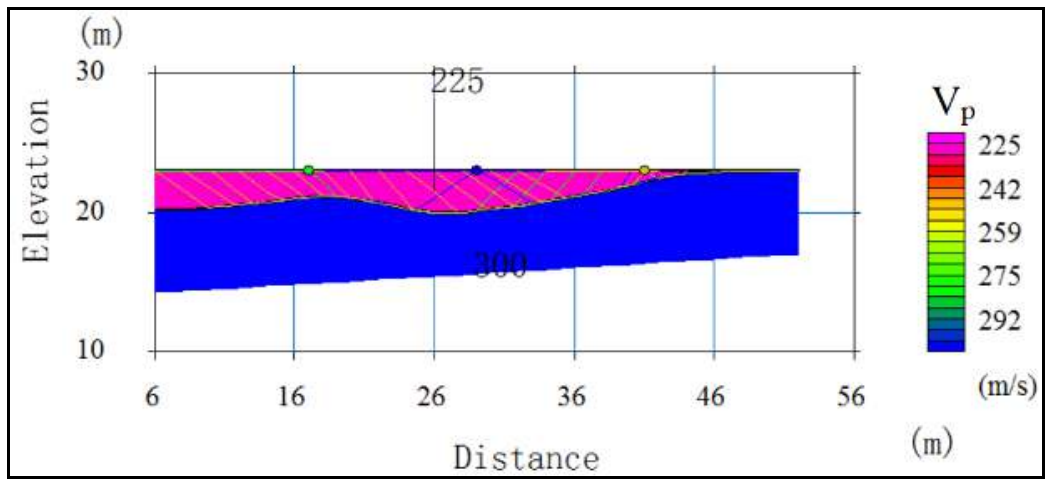

Gambar 10. Penampang model 2-D kecepatan gelombang $P\left(V_{p}\right)$ pada lokasi 4

Untuk lokasi 5 terletak di Kelurahan Nusa Indah Kecamatan Ratu Agung (Gambar 11). Formasi batuan pada lokasi ini berupa Batugamping Terumbu (Q1) dengan nilai $V_{p}$ pada lapisan pertama adalah $312 \mathrm{~m} / \mathrm{s}$ dan pada lapisan kedua adalah $382 \mathrm{~m} / \mathrm{s}$, sedangkan pada lapisan ketiga adalah $401 \mathrm{~m} / \mathrm{s}$. Satuan Formasi Batugampung Terumbu (Q1) termasuk dalam urutan Sedimen Kuarter yang berumur Holosen. Lokasi 6 berada di Kelurahan Bentiring Kecamatan Muara Bangkahulu dengan formasi batuan berupa Formasi Bintunan (QTb) (Gambar 12). Nilai $V_{p}$ pada lokasi ini adalah $310 \mathrm{~m} / \mathrm{s}$ untuk lapisan pertama dan $410 \mathrm{~m} / \mathrm{s}$ untuk lapisan kedua. Satuan Batuan Formasi Bintunan (QTb) berumur PliosenPlistosen dan menindih Formasi Andesit (Tpan) yang lebih tua [7]. Hasil studi yang dilakukan pada enam lokasi penelitian di Kota Bengkulu ini, maka dapat dirangkum hubungan tingkat kekerasan batuan, densitas bulk, dan formasi batuannya sebagaimana tercantum pada Tabel 2.

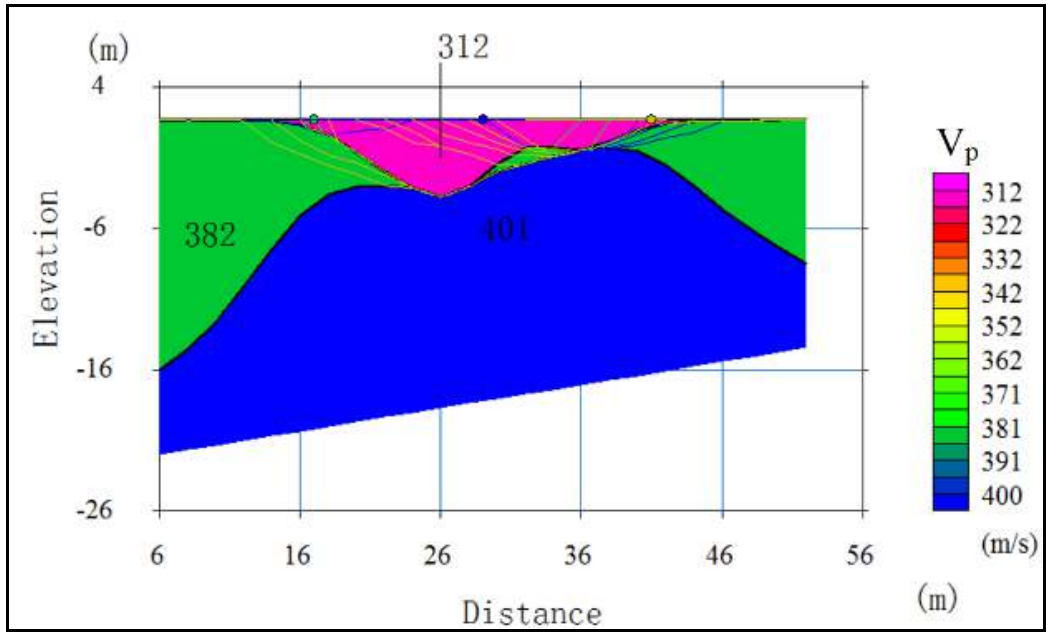

Gambar 11. Penampang model 2-D kecepatan gelombang $P\left(V_{p}\right)$ pada lokasi 5 


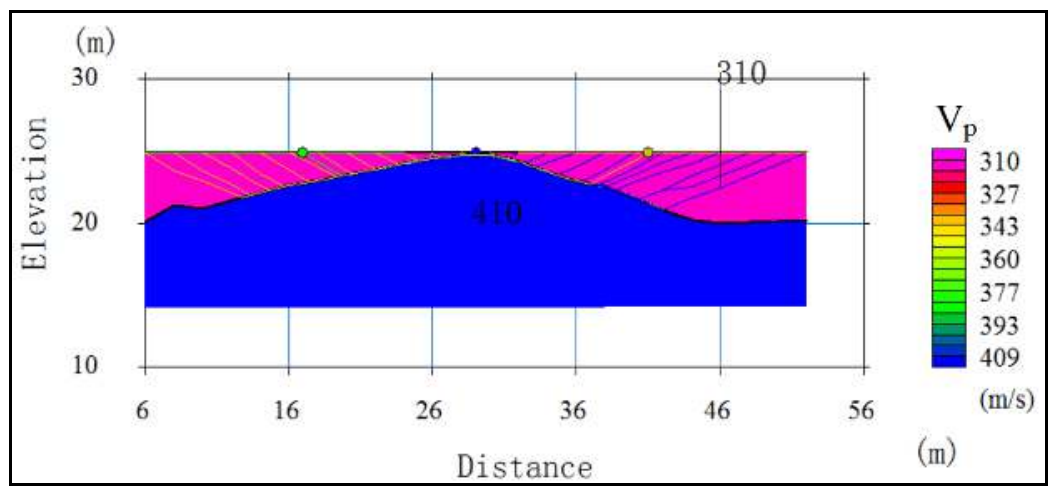

Gambar 12. Penampang model 2-D kecepatan gelombang $P\left(V_{p}\right)$ pada lokasi 6

Tabel 2. Hubungan tingkat kekerasan batuan berdasarkan kecepatan gelombang $P\left(V_{p}\right)$, densitas bulk $\left(\rho_{b}\right)$, dan formasi batuan di Kota Bengkulu

\begin{tabular}{|c|c|c|c|c|c|c|}
\hline $\begin{array}{c}V_{p} \\
\text { rerata } \\
(\mathbf{m} / \mathbf{s})\end{array}$ & $\begin{array}{c}\rho_{\mathbf{b}} \\
\left(\mathrm{g} / \mathrm{cm}^{3}\right)\end{array}$ & $\begin{array}{l}\text { Formasi } \\
\text { batuan }\end{array}$ & Litologi & Runtunan & Umur & $\begin{array}{l}\text { Lokas } \\
\quad \text { i }\end{array}$ \\
\hline 438,5 & 1,42 & $\begin{array}{l}\text { Andesit } \\
\text { (Tpan) }\end{array}$ & Pasir dan kerakal & Tersier & Miosen Akhir & 3 \\
\hline 365 & 1,35 & $\begin{array}{l}\text { Batugamping } \\
\text { Terumbu (Q1) }\end{array}$ & Batugamping terumbu & Kuarter & Holosen & 5 \\
\hline 360 & 1,35 & $\begin{array}{l}\text { Formasi } \\
\text { Bintunan } \\
(\mathrm{QTb})\end{array}$ & $\begin{array}{l}\text { Konglomerat, breksi, } \\
\text { dan batulempung tufan }\end{array}$ & Tersier & $\begin{array}{l}\text { Pliosen- } \\
\text { Plistosen }\end{array}$ & 6 \\
\hline 342 & 1,33 & Aluvium (Qa) & $\begin{array}{l}\text { Bongkah, kerakal, } \\
\text { pasir, lumpur, dan } \\
\text { lempung }\end{array}$ & Kuarter & Holosen & 2 \\
\hline 301 & 1,29 & $\begin{array}{c}\text { Undak } \\
\text { Aluvium (Qat) }\end{array}$ & $\begin{array}{l}\text { Kerikil, pasir, dan } \\
\text { lempung-lumpur }\end{array}$ & Kuarter & Holosen & 1 \\
\hline 262,5 & 1,25 & $\begin{array}{l}\text { Aluvium (Qa) } \\
\text { - Endapan } \\
\text { Rawa (Qs) }\end{array}$ & $\begin{array}{l}\text { Pasir, lanau, lumpur, } \\
\text { dan lempung } \\
\text { mengandung sisa } \\
\text { tumbuhan }\end{array}$ & Kuarter & Holosen & 4 \\
\hline
\end{tabular}

Berdasarkan Tabel 2, tingkat kekerasan batuan yang paling tinggi adalah Satuan Formasi Batuan Andesit (Tpan) yang berumur Miosen Akhir yang merupakan umur tertua di daerah studi. Litologi pada Tpan terdiri dari pasir dan kerakal ${ }^{[7]}$. Secara stratigrafi semakin tua umur suatu batuan, maka batuan tersebut akan semakin padat (keras) ${ }^{[25]}$. Hal ini dapat terlihat bahwa pada batuan Andesit dengan nilai $V_{p}$ rata-rata adalah $438,5 \mathrm{~m} / \mathrm{s}$ dan densitas bulk adalah $1,42 \mathrm{~g} / \mathrm{cm}^{3}$ merupakan yang paling besar di antara jenis batuan lainnya. Hasil ini juga dikuatkan oleh studi yang menyatakan bahwa Tpan termasuk ke dalam batuan tanah keras (hardsoil) ${ }^{[5]}$. Apabila dikaitkan dengan kejadian gempa bumi, maka lokasi ini akan relatif aman dari goncangan gempa karena tanahnya lebih keras dibandingkan di lokasi lain.

Satuan Formasi Batuan Andesit (Tpan) ini ditindih oleh Satuan Formasi Batuan Bintunan (QTb) yang berumur lebih muda yaitu Pliosen-Plistosen dengan formasi batuan berupa konglomerat, breksi, dan batulempug tufan. Nilai $V_{p}$ rata-rata pada Formasi Batuan Bintunan (QTb) adalah $360 \mathrm{~m} / \mathrm{s}$ dengan densitas bulk adalah $1,35 \mathrm{~g} / \mathrm{cm}^{3}$. Nilai $V_{p}$ rata-rata pada QTb yang diperoleh di lapangan lebih rendah sedikit daripada Q1 (batugamping 
terumbu). Hal ini diduga karena adanya pelapukan pada Satuan Formasi Batuan Bintunan (QTb) di lokasi tersebut dan mempengaruhi besarnya nilai $V p$. Selain itu, Batugamping Terumbu pada bagian bawahnya menjemari dengan Formasi Bintunan ${ }^{[7]}$, sehingga nilai $V_{p}$ dan densitas bulk-nya -nya hampir sama.

Satuan Batuan Aluvium (Qa), Undak Aluvium (Qat), Batugamping Terumbu (Q1), dan Endapan Rawa (Qs) merupakan Sedimen Kuarter yang berumur Holosen. Untuk Satuan Batuan Aluvium (Qa) mempunyai nilai $V_{p}$ dan densitas bulk yang lebih besar daripada Satuan Batuan Undak Aluvium (Qat) dan batuan peralihan antara Aluvium (Qa) dan Endapan Rawa (Qs). Litologi Aluvium terdiri dari bongkah, kerakal, pasir, lumpur, dan lempung, sedangkan Undak Aluvium terdiri dari kerikil, pasir dan lempung-lumpur. Untuk litologi Endapan Rawa terdiri dari pasir, lanau, lumpur, dan lempung yang mengandung sisa tumbuhan ${ }^{[7]}$. Berdasarkan litologinya tersebut, maka lokasi peralihan antara Qa dan Qs mempunyai nilai $V_{p}$ dan densitas bulk paling rendah. Nilai $V_{p}$ dan densitas bulk rendah ini berkaitan dengan material yang tidak padat, termasuk bagian dari unconsolidated sediment maupun sedimen lepas ${ }^{[26,27,28,29]}$. Untuk nilai $V_{p}$ dan densitas bulk yang rendah perlu diwaspadai ketika terjadi gempa bumi karena akan berdampak terhadap deformasi batuan yang lebih tinggi pada lokasi-lokasi tersebut. Hal ini berkaitan juga dengan tingkat kekerasan batuan yang kurang kompak. Namun demikian, apabila akan membangun sarana dan prasarana maupun infrastruktur di wilayah ini pondasinya harus sampai pada batuan yang keras atau batuan dasar. Pada studi ini, kedalaman batuan dasar bervariasi yaitu ada yang muncul ke permukaan hingga pada kedalaman tertentu. Batuan dasar yang paling dalam terdapat pada lokasi 5 yaitu 17,71 $\mathrm{m}$ dari permukaan.

Kerentanan terhadap gempa bumi suatu daerah dapat disebabkan oleh nilai regangan geser tanah. Nilai regangan geser tanah berpengaruh terhadap deformasi batuan yang akan terjadi ${ }^{[30]}$. Nilai regangan geser tanah di Kota Bengkulu bervariasi antara $10^{-6}$ hingga $>10^{-2}$ [4,9]. Nilai regangan geser tanah rendah $\left(10^{-6}-10^{-5}\right)$ sampai sedang $\left(10^{-4}-10^{-3}\right)$ pada lapisan tanah hanya mengalami getaran saja hingga settlement (penurunan tanah) dan masih bersifat elastis hingga plastis, tetapi nilai regangan geser tanah tinggi $>10^{-2}$ dapat mengalami pemadatan tanah, sehingga dapat menyebabkan deformasi tanah dan mempunyai karakteristik dinamika tanah bersifat collapse atau likuifaksi ${ }^{[31,32]}$. Semakin besar nilai regangan geser tanah, maka akan semakin rentan bila terjadi gempa bumi. Berdasarkan studi yang telah dilakukan, daerah yang mempunyai nilai $V_{p}$ dan densitas bulk rendah mempunyai nilai regangan geser lebih tinggi sekitar $10^{-3}{ }^{[4]}$ yaitu di lokasi 4 , lokasi 1, dan lokasi 2. Untuk nilai $V_{p}$ dan densitas bulk tinggi mempunyai nilai regangan geser lebih rendah yaitu sekitar $10^{-4}[4]$ berada di lokasi 6 , lokasi 5 , dan lokasi 3 . Hasil studi ini menunjukkan bahwa pada lokasi-lokasi penelitian ini mempunyai nilai regangan geser sedang dimana batuan masih bersifat elastis hingga plastis. Pada lokasi-lokasi yang mempunyai nilai $V_{p}$ dan densitas bulk rendah, jika terjadi goncangan gempa dapat mengalami penurunan tanah.

\section{KESIMPULAN}

Hasil studi menunjukkan bahwa tingkat kekerasan batuan berdasarkan kecepatan gelombang seismik dan densitas bulk pada beberapa formasi batuan berbeda bergantung jenis formasi batuannya. Satuan Formasi Batuan Andesit (Tpan) mempunyai tingkat kekerasan paling tinggi dengan $V_{p}$ rerata adalah $438,5 \mathrm{~m} / \mathrm{s}$ dan densitas bulk adalah 1,42 $\mathrm{g} / \mathrm{cm}^{3}$, sedangkan peralihan antara Satuan Formasi Batuan Aluvium (Qa) dan Satuan Formasi Batuan Endapan Rawa (Qs) mempunyai tingkat kekerasan paling rendah dengan $V_{p}$ rerata adalah $262,5 \mathrm{~m} / \mathrm{s}$ dan densitas bulk adalah $1,25 \mathrm{~g} / \mathrm{cm}^{3}$. Formasi batuan yang 
dapat berpotensi menyebabkan kerentanan terhadap bencana gempa bumi adalah formasi batuan yang mempunyai nilai kecepatan gelombang seismik dan densitas bulk paling rendah yang berkaitan dengan kurang kompaknya batuan tersebut. Pada wilayah studi ini kerentanan yang terjadi dipengaruhi juga oleh besarnya nilai regangan geser tanah. Untuk itu dalam membangun sarana dan prasarana di lokasi-lokasi ini harus lebih memperhatikan bangunan tahan gempa dan kedalaman batuan dasar. Batuan dasar yang terdeteksi terletak bervariasi dari permukaan hingga kedalaman $17,71 \mathrm{~m}$.

\section{UCAPAN TERIMAKASIH}

Penulis mengucapkan terima kasih setulusnya kepada Ketua Jurusan Fisika atas dukungan dana melalui "Penelitian Mandat Jurusan Fisika FMIPA Universitas Bengkulu TA 2020" dengan No. Kontrak: 2659/UN30.12/HK/2020.

\section{DAFTAR PUSTAKA}

1 Hadi, A.I., Farid, M. \& Fauzi, Y. 2012. Pemetaan Percepatan Getaran Tanah Maksimum dan Kerentanan Seismik Akibat Gempa Bumi untuk Mendukung Rencana Tata Ruang dan Wilayah (RTRW) Kota Bengkulu. J. Simetri, Vol. 1, No. 2(D), Hal. 1217-81-1217-86.

2 BMKG. 2010. Sejarah Gempa Bumi Bengkulu dari tahun 1900. Badan Meteorologi Klimatologi dan Geofisika. Bengkulu.

3 Irsyam, M., Sengara, W., Aldiamar, F., Widiyantoro, S., Triyoso, W., Hilman, D., Kertapati, E., Meilano, I., Suhardjono, Asrurifak, M. \& Ridwan, M. 2010. Ringkasan Hasil Studi Tim Revisi Peta Gempa Indonesia 2010. Kementerian Pekerjaan Umum. Bandung.

4 Farid, M. \& Hadi, A.I. 2018. Measurement of Shear Strain in Map Liquefaction Area for Earthquake Mitigation in Bengkulu City. Telkomnika, Vol. 16, No. 4, Hal. 15971606.

5 Sugianto, N., Farid, M. \& Suryanto, W. 2016. Local Geology Condition of Bengkulu City Based on Seismic Vulnerability Index (Kg). ARPN J. Eng Appl Sci., Vol. 11, No. 7, Hal. 4797-4803.

6 Gafoer, S., Amin, T.C. \& Pardede. 2007. Geological map of Bengkulu Quadrangle, Sumatra, scale 1:250,000. Department of Mines and Energy. Bandung.

7 Gafoer, S., Amin, T.C. \& Pardede. 2012. Geology of the Bengkulu Quadrangle, Sumatra. Department of Mines and Energy. Bandung.

8 Mase, L.Z., Sugianto, N. \& Refrizon. 2020. Seismic Hazard Microzonation of Bengkulu City, Indonesia. Reseacrh Square, Vol. 1, No. 26.

9 Farid, M. \& Mase, L.Z. 2020. Implementation of Seismic Hazard Mitigation on the Basis of Ground Shear Strain Indicator for Spatial Plan of Bengkulu City, Indonesia. International Journal of Geomate, Vol. 18, No. 69, Hal. 199-207.

10 Sugianto, N., Farid, M. \& Suhendra. 2017. Kondisi Geologi Lokal Kota Bengkulu Berdasarkan Ground Shear Strain (GSS). Spektra: Jurnal Fisika dan Aplikasinya, Vol. 2, No. 1, Hal. 29-36.

11 Lubis, A.M. \& Hadi, A.I. 2005. Analisis Kecepatan Gelombang Seismik Bawah Permukaan di Daerah yang Terkena Dampak Gempa Bumi 4 Juni 2000 (Studi Kasus: Kampus Universitas Bengkulu). J. Gradien, Vol. 1, No. 2, Hal. 69-73.

12 Nurcandra, N., Darsono, \& Koesuma, S. 2013. Penentuan Tingkat Kekerasan Batuan Menggunakan Metode Seismik Refraksi di Jatikuwung Karanganyar. IJAP, Vol. 3, No. 1, Hal. 29-35. 
13 Akpan, A.E., Ilori, A.O. \& Essien, N. 2015. Geophysical Investigation of Obot Ekpo Landslide Site, Cross River State, Nigeria. Journal of African Earth Science, Vol. 109, Hal. 154-167.

14 Mahandani, H.S. 2017. Identifikasi Kerawanan Tanah Longsor dengan Menggunakan Metode Seismik Refraksi dan MASW di Desa Purwosari Kabupaten Kulonprogo. Skripsi, Universitas Gadjah Mada Yogyakarta.

15 Susilawati. 2004. Seismik Refraksi (Dasar Teori dan Akuisisi Data). Digitized by USU digital library, Universitas Sumatera Utara Medan.

16 Adnyawati, N.K., Efendi, R. \& Sabhan. 2012. Analisis Struktur Bawah Permukaan dengan Menggunakan Metode Seismik Refraksi di Universitas Tadulako. J. Natural Science, Vol. 1, No. 1, Hal. 17-26.

17 Sismanto. 2016. Pengantar Survei dengan Menggunakan Gelombang Seismik. Gerbang Media. Yogyakarta.

18 Putra, R.W. 2017. Identifikasi Tebal Lapisan Lapuk Menggunakan Metode Seismik Refraksi Tomografi di Sebelah Barat Saluran Irigasi KM 15,9 Kalibawang, Kulon Progo. Skripsi, Universitas Gadjah Mada Yogyakarta.

19 Anonim. 2009. SeisImager/2DTM Manual: Version 3.3 (Pickwin v. 4.0.1.5; Plotrefa v. 2.9.1.6), http://epsc.wustl.edu/ epsc454/manuals/SeisImager2DManualv3.3.pdf. Diak-ses tanggal 9 September 2020.

20 Setiawan, B. 2008. Pemetaan Tingkat Kekerasan Batuan Menggunakan Metode Seismik Refraksi. Skripsi, Universitas Indonesia Jakarta.

21 Schon, J.H. 1998. Physical Properties of Rock: Fundamentals and Principles of Petrophysics (Handbook of Geophysical Exploration Section I, Seismic Exploration, Volume: 18), $2^{\text {nd }}$ Edition. Elsevier Science Ltd. Oxford.

22 Nurdiyanto, B., Hartanto, E., Ngadmanto, D., Sunardi, B., \& Susilanto, P. 2011. Determination of Rocks Density Level using Seismic Refraction Method. Jurnal Meteorologi dan Geofisika, Vol. 12, No. 3, Hal. 211-220.

23 Gardner, G.H.F., Gardner, L.W. \& Gregory, A.R. 1974. Formation Velocity and Density-The Diagnostic Basics for Stratigraphics Traps. Geophysics, Vol. 39, No. 6, Hal. 770-780.

24 Mavko, G., Mukerji, T., \& Dvorkin, J. 1998. The Rock Physics Handbook. Cambridge University Press. New York.

25 Turcotte, D.L. \& Schubert, G. 2014. Geodynamics, $3^{\text {rd }}$ Edition. Camridge University Press. New York.

26 Burger, H.R. 1992. Exploration Geophysics of the Shallow Subsurface. Prentice Hall. New Jersey.

27 Schon, J.H. 2011. Physical Properties of Rock: A Workbook (Handbook of Petroleum Exploration and Production Volume: 8). Elsevier Science Ltd. Oxford.

28 Telford, W.M., Geldart, L.P. \& Sheriff, R.E. 1998. Applied Geophysics, ${ }^{\text {nd }}$ Edition. Cambridge University Press. London.

29 Reynolds, J.M. 1997. An Introduction to Applied and Environmental. John Wiley and Sons Ltd. Chichester.

30 Daryono. 2011. Indeks Kerentanan Seismik Berdasarkan Mikrotremor pada Setiap Satuan Bentuklahan di Zona Graben Bantul Daerah Istimewa Yogyakarta. Disertasi, Universitas Gadjah Mada Yogyakarta.

31 Ishihara, K. 1996. Soil Behaviour in Earthquake Geotechnics. Oxford University Press Inc. New York.

32 Oliveira, C.S., Roca, A., \& Goula, X. 2008. Assessing and Managing Earthquake Risk (Geo-scientific and Engineering Knowledge for Earthquake Risk Mitigation: developments, tools, techniques). Springer. The Netherlands. 